\title{
In Vitro Evaluation of Commercial Fungicides against Some of the Major Soil Borne Pathogens of Soybean
}

\author{
Shrishail S Navi ${ }^{1}$, Rajasab $\mathrm{AH}^{2}$ and Yang XB ${ }^{1}$ \\ ${ }^{1}$ Department of Plant Pathology and Microbiology, lowa State University, Ames, lowa, USA \\ ${ }^{2}$ Postgraduate Studies and Research in Botany, Gulbarga University, Gulbarga, Karnataka, India
}

Corresponding Author: Shrishail S Navi, Department of Plant Pathology and Microbiology, lowa State University, Ames, lowa, USA, Tel: 5152944517; Fax: 5152949420; E-mail: ssnavi@iastate.edu

Rec date: March 18, 2016; Acc date: March 29, 2016; Pub date: March 31, 2016

Copyright: (c) 2016 Navi SS, et al. This is an open-access article distributed under the terms of the Creative Commons Attribution License, which permits unrestricted use, distribution, and reproduction in any medium, provided the original author and source are credited.

\begin{abstract}
Four Strobilurin, two premix of Strobilurin and Triazole, and one pyrazole-carboxamide foliar fungicides were tested in a modified in vitro culture plug technique against Colletotrichum truncatum (CT), Fusarium virguliforme (FV), Macrophomina phaseolina (MP), Pythium irregulare (PI), Rhizoctonia solani (RS), and Sclerotinia sclerotiorum (SS) and three Strobilurin and two premixes against Septoria glycines (SG). Under aseptic conditions, a single 6-mm culture plug of actively growing individual fungus was placed inverted on one end inside periphery of 9-cm PDA plates and on the opposite end 6-mm sterilized blotter disc with $50-\mu l$ fungicide solution was placed. Tests against SG were by spreading $50-\mu \mathrm{l}$ spore suspension $\left(1 \times 10^{8}\right.$ spores $\left./ \mathrm{ml}\right)$ on to PDA and placing blotter disc with $50-\mu \mathrm{l}$ fungicide in the center. During 12-day incubation in 12-h photoperiod, assessed in vitro (i) effects of fungicides on growth of pathogens, (ii) sensitivity of pathogens to fungicides and (iii) persistence of fungicide tolerance in pathogens. All the fungicides except Sercadis, significantly $(P<0.05)$ reduced radial growth of $C T$, while Headline EC, Priaxor and Stratego YLD significantly reduced growth of FV, MP, RS and SS. Similarly, Sercadis was effective against RS, and Aproach and Quadris against FV. SG and CT showed significant $(P<0.05)$ sensitivity to most of the fungicides, FV, RS and SS showed significant sensitivity by forming inhibition zone between their growth ends and Headline EC, Priaxor and Stratego YLD discs. CT, MP and RS showed significant $(P<0.05)$ persistence to all the fungicides that is considered fungistatic effect.
\end{abstract}

Keywords: Fungicides; Strobilurin; Triazole; Pyrazole-caroxamide; Fungistatic effect; Soybean pathogens; Area under colony growth

\section{Introduction}

Soybean [Glycine $\max$ (L.) Merr.] is the leading oilseed crop produced and consumed in the world. According to Hymowitz et al., [1] as of 2013, soybean was grown in 70 countries with an annual production of 268 million metric tons $(\mathrm{mmt})$. Top eight leading producers of soybean are United States (31\%), Brazil (31\%), Argentina (19\%), China (5\%), India (4\%), Paraguay (3\%) and Canada (2\%). As of December 2015, USDA projection of World Soybean Production $2015 / 2016$ is $320.11 \mathrm{mmt}$ it is an increase of $1.11 \mathrm{mmt}$ or a $0.35 \%$ compared with 2014 [2].

Worldwide more than 200 pathogens are affecting soybean, of which at least 35 have been reported economically important [3]. Some of the important early season diseases in Iowa, United States are; Phytophthora root rot (Phytophthora spp.), Pythium damping off and root rot (Pythium spp.), Rhizoctonia root rot (Rhizoctonia solani) and sudden death syndrome (Fusarium virguliforme). Mid to late season diseases are brown spot (Septoria glycines), anthracnose (Colletotrichum spp.), sudden death syndrome ( $F$ virguliforme), charcoal rot (Macrophomina phaseolina), and white mold (Sclerotinia sclerotiorum). A comprehensive report of soybean diseases in Argentina, Brazil, Canada, China, India, Japan and United States have been compiled in the latest compendium of soybean diseases and pests [4]. The foliar, stem and root diseases of soybean are important components of yield loss in soybean fields. In Iowa, bacterial leaf blight
(Pseudomonas savastanoi pv. glycinea), frogeye leaf spot (Cercospora sojina), Cercospora leaf blight (C. kukuchii), downy mildew (Peronospora manshurica), and Septoria leaf spot or brown spot $(S$. glycines) are present without causing significant impact on yield [5]. However, these diseases do reduce photosynthetic activity in infected leaves by reducing green leaf area [6] and affecting photosynthesis in the asymptomatic area of diseases infection [6,7]. On the other hand yield losses due to stem and root diseases like Rhizoctonia root rot, Pythium and Phytophthora root rot, sudden death syndrome and white mold are up to $35 \%$ [8].

According to USDA-NASS [9] fungicides use in soybean has gone up from $<1 \%$ of the soybean planted acreage in 20 program states (Arkansas, Illinois, Indiana, Iowa, Kansas, Kentucky, Louisiana, Maryland, Michigan, Minnesota, Mississippi, Missouri, Nebraska, North Carolina, North Dakota, Ohio, South Dakota, Tennessee, Virginia, and Wisconsin) to $11 \%$ of soybean planted acres in 2012 . Similarly, quantity of fungicides applied on soybean has gone up from 48 metric ton in 2002 to 490 metric ton in 2012 on annual basis.

Several seed treatment products (chemical and biological) were tested against Fusarium spp., Pythium spp., R. solani, Phytophthora sojae [10], and against $S$. sclerotiorum both in vitro and field [11]. Also, some specific active ingredients like azoxystrobin [12-14], pyraclostrobin [15], trifloxystrobin [16], thiophanate-methyl [17], prothioconazole [18], and fludioxonil [13,15,19] tested against Fusarium spp. There are several such reports of testing seed treatment products against soil borne pathogens in cereals, legumes and oil seeds. Perhaps our approach is similar to [20] to identify potential and alternate use of foliar fungicides as seed treatment. As a first step, in 
vitro tests of some of the foliar fungicides against major soil borne pathogens of soybean is undertaken.

There are various in vitro methods to test efficacy of fungicides, like paper disc-agar diffusion technique [21], food poisoning technique [22], agar-well diffusion technique [23], poison plate tests and spore germination tests [24-26]. In the current study, a modified dual culture plug technique of Rahman et al., [27] was adopted to test foliar fungicides (Strobilurin, premix of Strobilurin and Triazole, and pyrazole-carboxamide) against major soil borne pathogens of soybean (C. truncatum, F virguliforme, M. phaseolina, P. irregulare, $R$. solani, and $S$. sclerotiorum and $S$. glycines). Objectives of the current study were to 1 . Assess in vitro effects of fungicides on growth of pathogens, 2. Assess in vitro sensitivity of pathogens to various fungicides and 3 . Assess in vitro tolerance of pathogens to fungicides. Eventually, to find an alternate use of these fungicides as potential seed treatment against several pathogens.

\section{Materials and Methods}

\section{Soybean pathogens}

Iowa field isolates of Colletotrichum truncatum (CT), Fusarium virguliforme (FV), Macrophomina phaseolina (MP), Pythium irregulare (PI), Rhizoctonia solani (RS), and Sclerotinia sclerotiorum
(SS) were isolated on potato dextrose agar (PDA) under aseptic conditions, and were maintained on PDA plates at $23 \pm 11^{\circ} \mathrm{C}$ throughout the study period. Septoria glycines (SG) isolate $14 \mathrm{Sg} 1-23$ grown on V8 juice medium (with Rifamycin) was collected from Dept. of Crop Sciences, University of Illinois at Urbana-Champaign, Illinois under an USDA permit and was maintained on V8 juice medium. To maintain on V8 juice medium, added 1-ml distilled sterile water to wash off oozing out conidia, rubbed the growth with a disposable Lazy-L-spreaders (Research Products International Corp.) to loosen the conidia. Pipetted $50-\mu \mathrm{l}$ to a fresh V8 plate and spread with a presterilized polystyrene disposable lazy-L-spreader, incubated at $23 \pm 1{ }^{\circ} \mathrm{C}$ in $12 \mathrm{~h}$ light on $12 \mathrm{~h}$ off cycle for a week.

\section{Fungicides and stock solution preparation}

Foliar fungicides picoxystrobin $\left(\right.$ Aproach $\left.{ }^{\circledR}\right)$, fluoxastrobin $\left(\right.$ Evito $\left.^{\circ}\right)$, pyraclostrobin (Headline EC ${ }^{\bullet}$ ) and azoxystrobin (Quadris ${ }^{\star}$ ), pyraclostrobin + fluxapyroxad (Priaxor ${ }^{\circledR}$ ), trifloxystrobin + prothioconazole (Stratego YLD $\left.{ }^{\circ}\right)$, and fluxapyroxad $\left(\right.$ Sercadis $\left.{ }^{\circ}\right)$ were evaluated against CT, FV, MP, PI, RS, and SS. Whereas, against $S$. glycines only Aproach, Headline EC, Priaxor, Quadris, and Stratego YLD were evaluated. List of fungicides, labeled application rates, active ingredients, group name, FRAC code and manufacturer is provided in Table 1.

\begin{tabular}{|c|c|c|c|c|c|c|}
\hline $\begin{array}{l}\text { Fungicide } \\
\text { product }\end{array}$ & $\begin{array}{l}\text { Dilutions } \\
\text { used }(\mathrm{ml} / \mathrm{L})^{1}\end{array}$ & $\begin{array}{l}\text { Labeled } \\
\text { rates }^{2} \\
\mathrm{ml} / \mathrm{Ac}\end{array}$ & Active ingredient (\%) & $\begin{array}{l}\text { Group } \\
\text { name }\end{array}$ & $\begin{array}{l}\text { FRAC* } \\
\text { code }\end{array}$ & Manufacturer \\
\hline Aproach $^{\circledR}$ & 3.1 & 177.4 & Picoxystrobin 22.5 & Qol & 11 & DuPont \\
\hline Evito ${ }^{\circledR} 480 S C$ & 1.0 & 59.1 & Fluoxastrobin 40.3 & Qol & 11 & Arysta \\
\hline Headline ${ }^{\circledR} 2.08 \mathrm{EC}$ & 3.1 & 177.4 & Pyraclostrobin 23.6 & Qol & 11 & BASF \\
\hline Priaxor $^{\circledR}$ & 2.1 & 118.3 & $\begin{array}{l}\text { Fluxapyroxad } 14.33+ \\
\text { Pyraclostrobin } 28.58\end{array}$ & $\begin{array}{l}\text { Carboxamides } \\
+ \text { Qol }\end{array}$ & 7,11 & BASF \\
\hline Quadris $^{\circledR}$ & 3.1 & 177.4 & Azoxystrobin 22.9 & Qol & 11 & Syngenta \\
\hline Sercadis $^{\circledR}$ & 1.4 & 79.8 & Fluxapyroxad 26.55 & Carboxamides & 7 & BASF \\
\hline Stratego ${ }^{\circledR}$ YLD & 2.1 & 118.3 & $\begin{array}{l}\text { Prothioconazole } 10.8+ \\
\text { Trifloxystrobin } 32.3\end{array}$ & $\mathrm{DMI}+\mathrm{Qol}$ & 3,11 & Bayer \\
\hline
\end{tabular}

Table 1: List of fungicides tested in in vitro on major soybean pathogens. ${ }^{1}$ Dilutions were based on ${ }^{2}$ labeled spray rates mixed in 56.7 liter of water. $\mathrm{SC}=$ Suspension concentrate; EC = Emulsifiable concentrate; QoI fungicides = Quinone outside inhibitors; DMI fungicides = DeMethylation inhibitors; ${ }^{\star}$ Fungicide Resistance Action Committee.

Under aseptic conditions, in a pre-disinfected NuAire class II type B2 biological safety cabinet, syringed $3.1-\mathrm{ml}$ of product individually from the containers of Aproach, Headline EC, and Quadris, and transferred separately to conical flasks containing 1-liter sterilized deionized water (SDW). Each of the dilution was well mixed by stirring on thermolyne magnetic stir plate for two minutes. Similarly, the stock solutions of other fungicides were prepared (syringed 1-ml of Evito, 2.1-ml of Priaxor, 1.4-ml of Sercadis and 2.1-ml of Stratego YLD and were transferred separately in 1-liter SDW).

\section{Plating and incubation}

The fungal isolates were subcultured on a 5-mm thick PDA in 9-cm disposable petri dishes. In a modified dual culture plug technique [27], a single $6-\mathrm{mm}$ culture plug taken from the edges of actively growing cultures using sterile cork borer, and placed inverted on one end inside periphery of PDA dishes and on the opposite end 6-mm sterilized blotter disc (Anchor Paper Co. Minnesota) was placed and soon after, $50-\mu$ fungicide solution was transferred on the disc using microliter pipette (Rainin instrument Co., Inc, California) under aseptic conditions. To test against $S$. glycines, $50-\mu \mathrm{l}$ spore suspension $\left(1 \times 10^{8}\right.$ spores/ml) was spread on to V8-plates using disposable Lazy-Lspreaders and transferred $50-\mu$ l fungicide solution on blotter disc 
placed in the center. Each lidded plate was sealed with parafilm (Bemis Flexible Packaging, 2301 Industrial Drive Neenah, WI 54956) against moisture and air contamination. Sealed plates were transferred to predisinfected clear square plastic container (interior dimensions $25.4 \times 17.8 \times 7.6 \mathrm{~cm}$ Pioneer Plastics, Inc. KY 42409) and were incubated at $23 \pm 1^{\circ} \mathrm{C}$ in $12 \mathrm{~h}$ fluorescent light at visible light intensity of 0.42 $\mathrm{w} / \mathrm{m}^{2}$ (measured using PMA2100, Solar light company, Inc. 100 East Glenside Ave, Glenside, Pennsylvania) for 12 days. There were four replications for each of the pathogen and fungicide combination and control plates.

\section{Assessment of in vitro effects of fungicides on growth of pathogens}

Radial growth rates ( $\mathrm{mm} /$ day) of pathogens in presence and absence of fungicides was measured from the edge of the culture plug. Also documented photographs of culture plates with or without fungicide discs. Percent reduction in radial growth of pathogens in presence of fungicides compared with control was calculated following the formula given below,

Reduction $(\%)$ in radial growth of pathogen $=(\mathrm{GAF}-\mathrm{GPF}) \div \mathrm{GAF}$ $\times 100$.

Where, GAF= Radial growth or radius of pathogen in the absence of fungicide and
$\mathrm{GPF}=$ Radial growth or radius of pathogen in the presence of fungicide (Figure 1A).

\section{Assessment of in vitro sensitivity of pathogens to fungicides}

Inhibition zone formation is an indication of fungicidal or lethal effect of fungicides on growth and reproduction of pathogens. In other words, sensitivity of pathogens to fungicides. To assess the sensitivity, inhibition zone size $(\mathrm{mm})$ between growth end of pathogen and edge of fungicide disc or inhibition zone size diameter $(\mathrm{mm})$ around fungicide disc (only in $S$. glycines) was measured (Figure 1B). Also documented photographs of visual inhibition zone formed between pathogens and fungicide disc.

\section{Assessment of in vitro persistence of pathogens' tolerance to fungicides}

Fungistatic effect (Figure 1C) is inhibiting growth of fungi without destroying them or inhibiting the growth of fungi temporarily [28-30]. Fungistatic effect is seen because of fungicides diffusion on synthetic medium. The Fungistatic effects of fungicides was measured $(\mathrm{mm})$ at least in three pathogens, also documented photographs of Fungistatic effects.

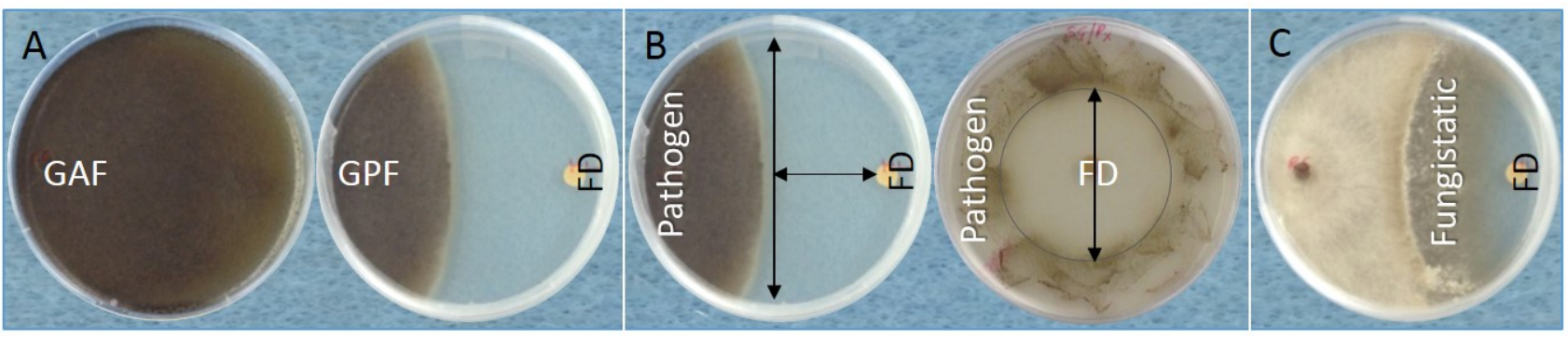

Figure 1: Measurement of $(\mathrm{A})$ percent reduction in radial growth of pathogen $=(\mathrm{GAF}-\mathrm{GPF}) \div \mathrm{GAF} \times 100$. Where, GAF is radial growth of pathogen in the absence of fungicide disc (FD) and GPF is radial growth of pathogen in the presence of FD, (B) inhibition zone between growth end of pathogen and edge of FD or around FD and (C) Fungistatic effect is inhibiting growth of fungi temporarily without destroying them.

\section{Assessment of area under colony growth}

The area under colony growth of fungi was measured using individual digital images at Image Analysis Facility, Office of Biotechnology, Iowa State University, Ames, Iowa. Individual digital pictures of fungi grown on 9-cm PDA Petri dish, either with fungicide disc (FD) placed on opposite end of test fungus or without FD were taken using Leica V-Lux 30. Using Petri dish size as parameter, the ImageJ software [31] was calibrated for each set of Petri dishes prior to measurement of the colony growth using the Set Scale function of ImageJ (v. 1.45s). All measurements were done in square $\mathrm{cm}$. To quantify the area occupied by the fungus, each colony area on the color images was outlined. The color images were then split into individual red, green, and blue channels using the Split Channels function. The resulting image with the best contrast between the background and the outline was interactively thresholded to isolate the outlines using the Threshold function. The outlines were then filled and individually measured using the Fill Holes and Measure functions, respectively. The resulting measurements were transferred to a spreadsheet for further analysis.

\section{Data analysis}

Mean radial growth of pathogens in presence and absence of fungicides, reduction percent in growth of pathogens compared with control, sensitivity of pathogens to fungicides and fungicide tolerance of pathogens was analyzed using PROC ANOVA in SAS 9.4. (SAS, LLC, Cray, NY). Fisher's least significant difference was used to detect the significant differences among the means $(\mathrm{P}=0.05)$.

\section{Results}

\section{In vitro effects of fungicides on growth of pathogens}

In control plates, $P$. irregulare and $S$. sclerotiorum reached the opposite end of the plate within 4 days, followed by $M$. phaseolina, and $R$. solani in 8 days and $C$. truncatum in 20 days but $F$. virguliforme 
Page 4 of 8

didn't reach periphery with an incubation of 24 days. In an in vitro assay, we investigated whether pathogens can grow efficiently on PDA in presence of fungicide disc placed on the opposite end of culture plug. All the six fungicides significantly $(\mathrm{P}<0.05)$ reduced radial growth of $C$. truncatum compared with control in 12 days after incubation (DAI). However, reduction (\%) in growth varied depending on fungicide on the opposite end (Figures $2 \mathrm{~A}$ and $2 \mathrm{~B}$ ). Reduction in radial growth of $C$. truncatum was significantly $(\mathrm{P}<0.05)$ highest in Headline EC and Stratego YLD (62.7\%) followed by Priaxor and Quadris (55.2\%), Aproach (50.7\%), Evito (49.6\%) and only $2.9 \%$ in Sercadis (Figure 2A). Reduction in radial growth of $F$. virguliforme was significantly highest in Stratego YLD (50\%) followed by $44 \%$ in Aproach and Priaxor, 22\% in Headline EC and 6\% in Quadris (Figure $2 \mathrm{~A})$. However, Evito and Sercadis were not different from the control plates (Figure 2A). In $M$. phaseolina, significantly $(\mathrm{P}<0.05)$ highest reduction in radial growth was observed in Stratego YLD (49\%) followed by Priaxor (35\%) and Headline EC (24\%) compared with control plates and other four fungicides (Figure 2A). Compared with control plates, plates with Priaxor significantly $(\mathrm{P}<0.05)$ reduced the radial growth of P. irregulare (26\%) followed by Headline EC (24\%), Quadris (21\%), Aproach (21\%), Evito (14\%) and Stratego YLD (14\%) in $4 \mathrm{DAI}$ (data not shown in Figure 2A).



Figure 2: (A) Mean percent reduction in radial growth of Colletotrichum truncatum (CT), Fusarium virguliforme (FV), Macrophomina phaseolina (MP), Pythium irregulare (PI), Rhizoctonia solani (RS), and Sclerotinia sclerotiorum (SS) in presence of fungicide disc compared with control on PDA plates in 12 days after incubation and (B) colony growth, sensitivity and fungistatic effects on individual pathogens in presence of fungicide disc compared with control. Means in individual pathogens followed by the same letter(s) are not significantly different from each other at $5 \%$ level of significance $(\mathrm{P}<0.05)$.
However, none of the fungicides had any effect on $P$. irregulare compared with control in extended incubation of 12 days (Figures $2 \mathrm{~A}$ and 2B). In $R$. solani, significant reduction was observed in plates with Priaxor (54\%), followed by Headline EC (35\%), Stratego YLD (29\%) and Sercadis (24\%). However, Aproach, Evito, and Quadris fungicides had no impact on growth of $R$. solani compared with control plates (Figures 2A and 2B). In S. sclerotiorum, Stratego YLD showed 39\% reduction in radial growth, followed by Priaxor (38\%) and Headline EC (3\%). Apart from reducing the mycelial growth of $S$. sclerotiorum, Stratego YLD, Priaxor and Headline EC also significantly $(\mathrm{P}<0.05)$ reduced sclerotia production compared with other fungicides treatments and control (Figure 2B). However, Aproach, Evito, Quadris, and Sercadis did not show any reduction in growth and reproduction of S. sclerotiorum (Figures $2 \mathrm{~A}$ and $2 \mathrm{~B}$ ).

\section{In vitro sensitivity of pathogens to fungicides}

Inhibition zone (IZ) formation is an indication of sensitivity of pathogens to fungicides in their growth and reproduction. All the seven fungicides significantly $(\mathrm{P}<0.05)$ formed IZ between growth end of $C$. truncatum and fungicide disc except Sercadis (Figure 3A).



Figure 3: (A) Mean growth inhibition zone size $(\mathrm{mm})$ between the growth ends of pathogens and edge of fungicide disc on PDA, and (B) Mean growth inhibition zone diameter size $(\mathrm{mm})$ of Septoria glycines around fungicide disc placed in the center of PDA plates in 12 days after incubation. Pathogens: C. truncatum (CT), F. virguliforme (FV), M. phaseolina (MP), P. irregulare (PI), R. solani (RS), S. glycines (SG) and S. sclerotiorum (SS). Means in individual pathogens followed by the same letter(s) are not significantly different from each other at $5 \%$ level of significance $(\mathrm{P}<0.05)$.

Highest IZ was observed in plates with Stratego YLD $(34 \mathrm{~mm})$, followed by Headline EC (33 mm), Evito (30 mm), Quadris $(29 \mathrm{~mm})$, Priaxor (26 mm), and Aproach (24 mm). In F virguliforme, Headline 
EC had the highest IZ $(11 \mathrm{~mm})$ compared with $10 \mathrm{~mm}$ in Aproach, Priaxor, and Stratego YLD. However, there was no IZ observed in plates with Evito, Quadris and Sercadis (Figure 3A). Stratego YLD showed significant $(\mathrm{P}<0.05)$ IZ $(15 \mathrm{~mm})$ in $M$. phaseolina followed by Priaxor ( $5 \mathrm{~mm}$ ), and none of the other fungicides tested showed any IZ (Figure 3A). P. irregulare, did not show sensitivity to any of the fungicides tested in $12 \mathrm{DAI}$ (Figure $3 \mathrm{~A}$ ), but in $4 \mathrm{DAI}$, in plates with Aproach and Stratego YLD the IZ was $10-\mathrm{mm}$, followed Priaxor with 8 $\mathrm{mm}$, and Evito and Headline EC with $5 \mathrm{~mm}$ (data not shown). $R$. solani plated with Priaxor showed significantly $(\mathrm{P}<0.05)$ highest IZ $(18$ $\mathrm{mm}$ ) followed by $5 \mathrm{~mm}$ in Headline EC and Stratego YLD, and $3 \mathrm{~mm}$ in Sercadis (Figure 3A). In S. sclerotiorum, plates with Stratego YLD showed significantly highest IZ $(20 \mathrm{~mm})$ followed Priaxor $(11 \mathrm{~mm})$ and Headline EC $(2 \mathrm{~mm})$ and other four fungicides did not form any IZ against $S$. sclerotiorum (Figure $3 \mathrm{~A}$ ).

In case of $S$. glycines, plating was different from six other pathogens tested. Significantly highest IZ diameter $(50 \mathrm{~mm})$ was observed in plates with Priaxor followed by Stratego YLD $(29 \mathrm{~mm})$, Headline EC $(17 \mathrm{~mm})$, Quadris $(10 \mathrm{~mm})$ and Aproach $(4 \mathrm{~mm})$ compared with control (Figure 3B).

\section{In vitro persistence of fungicide tolerance in pathogens}

Fungistatic effect is inhibiting growth of fungi without destroying them or inhibiting the growth of fungi temporarily [28-30]. All fungicides except Sercadis showed Fungistatic effect. With an increased incubation period, odds of observing Fungistatic effect are more if the product has the ability to slower the growth rate of pathogens. This happens because of fungicides diffusion on synthetic medium. During diffusion process fungicide moves down the concentration gradient, that means, concentration of fungicide is higher where the disc was placed, away from the disc, concentration reduces due to diffusion. Fungistatic effect was observed only in $C$. truncatum, $M$. phaseolina and $R$. solani starting 8 DAI. The Fungistatic effect on $C$. truncatum was significantly higher $(8 \mathrm{~mm})$ in plates with Headline EC and Aproach followed by Evito, Priaxor, and Stratego YLD each with $5 \mathrm{~mm}$ in 8 DAI. While in 12 DAI, Fungistatic effect on $C$. truncatum was significantly higher $(14 \mathrm{~mm})$ in plates with Aproach, Evito, and Quadris, followed by Priaxor with $11 \mathrm{~mm}$, and Headline EC and Stratego YLD with $8 \mathrm{~mm}$ (Figures 4A and 4B).

The Fungistatic effect on $M$. phaseolina was observed within 4 DAI. Significantly highest $(27 \mathrm{~mm})$ Fungistatic effect was observed in plates with Quadris followed by Headline EC $(25 \mathrm{~mm})$, Priaxor and Stratego YLD (16 mm), Aproach (14 mm), Sercadis (14 mm), and Evito (8 mm) in 4DAI. Whereas, in $8 \mathrm{DAI}$, significant Fungistatic effect size of 27 $\mathrm{mm}$ was observed in Aproach, Headline EC, Quadris, Sercadis, and Stratego YLD compared with Priaxor $(16 \mathrm{~mm})$ and Evito $(14 \mathrm{~mm})$. In 12 DAI, significantly highest $(41 \mathrm{~mm})$ Fungistatic effect was observed in Quadris, compared with Headline EC (33 mm), Aproach, Evito, and Stratego YLD with $27 \mathrm{~mm}$. and Priaxor with $16 \mathrm{~mm}$. However, Fungistatic effect in Sercadis reduced from $27 \mathrm{~mm}$ in 8DAI to zero in 12DAI (Figures $4 \mathrm{~A}$ and $4 \mathrm{~B}$ ).

Similar to M. phaseolina, the Fungistatic effect on $R$. solani was also observed within 4 DAI. Significantly highest $(14 \mathrm{~mm})$ Fungistatic effect was observed in plates with Sercadis followed by Evito $(11 \mathrm{~mm})$, whereas in plates with Aproach, Headline EC, Priaxor, and Quadris with $8 \mathrm{~mm}$ and Stratego YLD did not show Fungistatic effect in 4 DAI. In 8 DAI, significantly highest $(35 \mathrm{~mm}$ ) Fungistatic size was observed in Quadris, followed by plates with Aproach, Evito and Sercadis 27 $\mathrm{mm}$, Headline EC $(22 \mathrm{~mm})$ Priaxor $(19 \mathrm{~mm})$ and Stratego YLD (14 $\mathrm{mm})$. Whereas, in 12 DAI, Fungistatic size in Aproach, Headline EC, Quadris and Sercadis was $46 \mathrm{~mm}$, followed by Evito $(41 \mathrm{~mm})$, and Priaxor and Stratego YLD with $27 \mathrm{~mm}$ each. (Figures $4 \mathrm{~A}$ and $4 \mathrm{~B}$ ).

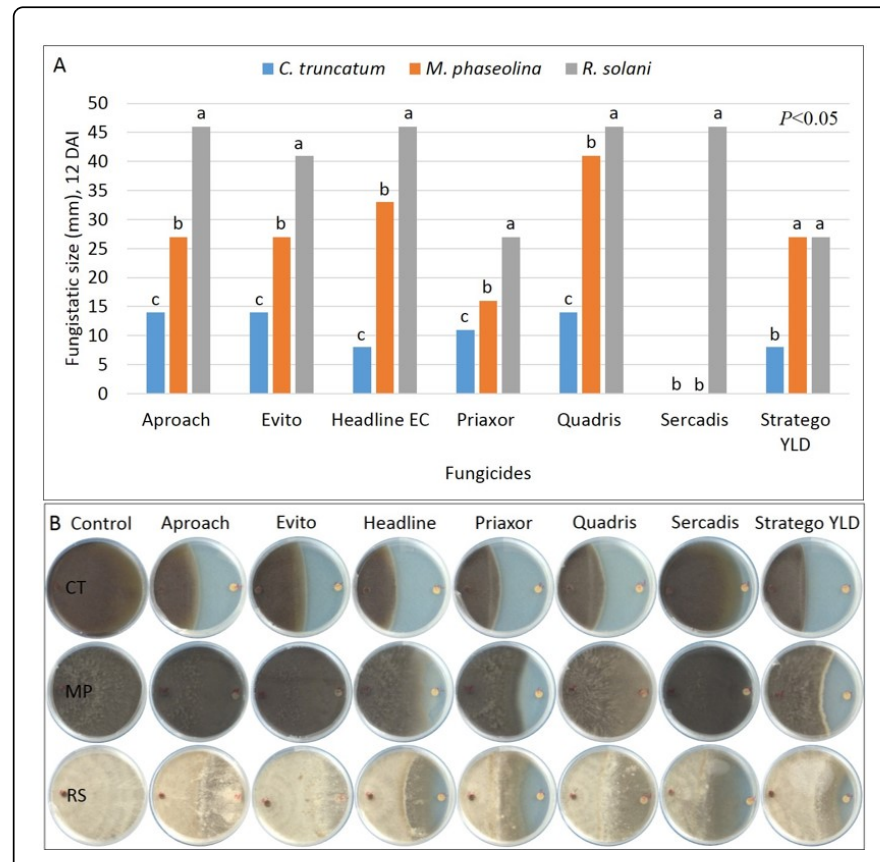

Figure 4: (A) Mean fungistatic effect size ( $\mathrm{mm}$ ) of $C$. truncatum, $M$. phaseolina and $R$. solani and (B) corresponding images showing fungistatic effect on PDA plates sown with fungicide disc on the opposite end compared with their controls. Means of fungi followed by the same letter(s) in each fungicide are not significantly different from each other at $5 \%$ level of significance $(\mathrm{P}<0.05)$.

\begin{tabular}{|l|l|l|l|l|l|l|l|}
\hline \multicolumn{7}{|l|}{ Area under colony growth $\left(\mathrm{cm}^{2}\right)$} \\
\hline Treatments & CT & FV & MP & PI & RS & SG & SS \\
\hline Control & $59.5 \mathrm{a}$ & $17.1 \mathrm{a}$ & $63.6 \mathrm{a}$ & $63.6 \mathrm{a}$ & $63.6 \mathrm{a}$ & $63.6 \mathrm{a}$ & $63.6 \mathrm{a}$ \\
\hline Aproach $^{\circledR}$ & $32.1 \mathrm{~d}$ & $12.1 \mathrm{~g}$ & $63.6 \mathrm{a}$ & $63.6 \mathrm{a}$ & $63.6 \mathrm{a}$ & $63.6 \mathrm{a}$ & $63.6 \mathrm{a}$ \\
\hline Evito $^{\circledR} 480 \mathrm{SC}$ & $39.8 \mathrm{c}$ & $15.8 \mathrm{~d}$ & $63.6 \mathrm{a}$ & $63.6 \mathrm{a}$ & $63.6 \mathrm{a}$ & $-^{*}$ & $63.6 \mathrm{a}$ \\
\hline Headline $^{\circledR} 2.08 \mathrm{EC}$ & $26.4 \mathrm{~h}$ & $14.1 \mathrm{e}$ & $60.3 \mathrm{~b}$ & $63.6 \mathrm{a}$ & $54.3 \mathrm{c}$ & $58.0 \mathrm{~b}$ & $57.2 \mathrm{c}$ \\
\hline Priaxor $^{\circledR}$ & $29.2 \mathrm{~g}$ & $12.9 \mathrm{f}$ & $55.7 \mathrm{c}$ & $63.6 \mathrm{a}$ & $44.8 \mathrm{e}$ & $42.4 \mathrm{~d}$ & $53.4 \mathrm{~d}$ \\
\hline Quadris $^{\circledR}$ & $31.1 \mathrm{e}$ & $16.1 \mathrm{c}$ & $63.6 \mathrm{a}$ & $63.6 \mathrm{a}$ & $63.6 \mathrm{a}$ & $63.6 \mathrm{a}$ & $63.6 \mathrm{a}$ \\
\hline Sercadis $^{\circledR}$ & $54.1 \mathrm{~b}$ & $16.9 \mathrm{~b}$ & $63.6 \mathrm{a}$ & $63.6 \mathrm{a}$ & $54.8 \mathrm{~b}$ & - & $61.9 \mathrm{~b}$ \\
\hline Stratego $^{\circledR}$ YLD & $30.0 \mathrm{f}$ & $10.0 \mathrm{~h}$ & $45.2 \mathrm{~d}$ & $63.6 \mathrm{a}$ & $52.4 \mathrm{~d}$ & $55.3 \mathrm{c}$ & $44.8 \mathrm{e}$ \\
\hline
\end{tabular}

Table 2: ${ }^{1}$ Mean area under colony growth $\left(\mathrm{cm}^{2}\right)$ of Colletotrichum truncatum (CT), Fusarium virguliforme (FV), Macrophomina phaseolina (MP), Pythium irregulare (PI), Rhizoctonia solani (RS), Septoria glycines (SG) and Sclerotinia sclerotiorum (SS) in presence and absence (control) of fungicide disc on PDA plates in 12 days after incubation. ${ }^{1}$ Results are average of four plates. Means within column followed by the same letter(s) are not significantly different from each other at $5 \%$ level of significance $(\mathrm{P}<0.05)$. ${ }^{\star}$ Not tested. 


\section{Area under colony growth}

The mean area $(\mathrm{cm} 2)$ under colony growth (AUCG) of $C$ truncatum and $F$. virguliforme was significantly $(\mathrm{P}<0.05)$ less in plates with fungicide discs compared with control (Table 2). The AUCG of $M$. phaseolina was significantly less in plates with Stratego YLD, Priaxor and Headline EC compared with control and other fungicides. Similarly, the AUCG of $R$. solani, $S$. glycines and $S$. sclerotiorum was significantly $(\mathrm{P}<0.05)$ less in Priaxor, Headline, Stratego YLD and Sercadis compared with control and other fungicides (Table 2).

\section{Discussion}

Fungicides toxic to fungi affect in several ways. The mycelium may cease growing, change metabolic processes or be killed, spores may fail to germinate or be killed [31]. Fungicides tested in this study were foliar applied to control various diseases and or for plant health benefits in soybean. Results of quadruplicate for each combination of pathogen and fungicide have significantly $(\mathrm{P}<0.05)$ reduced radial growths of majority of pathogens tested compared with controls. Headline, Priaxor and Stratego YLD fungicides were effective against all the pathogens tested except $P$. irregulare. Overall, Aproach was effective against $C$. truncatum, $F$. virguliforme and $S$. glycines, Evito against $C$. truncatum, Quadris against $C$. truncatum, $F$. virguliforme and $S$. glycines, and Sercadis $C$. truncatum and $R$. solani. However, degree of effectiveness of fungicides tested against seven pathogens varied based on their growth rates and sensitivity to fungicides. Another parameter used to compare the effectiveness of fungicides was area under colony growth on ImageJ software [32]. Results of this study indicate that, the higher the area under colony growth (AUCG), lower the effect of fungicide against a fungi (Table 2). It is important to note that AUCG doesn't exclude fungistatic effect showed in Figures $4 \mathrm{~A}$ and $4 \mathrm{~B}$.

After reviewing product labels, we tend to believe that in vitro test results either complement the assertion on the label or differ and provide additional information to the label (pending, either seed treatment or foliar field tests). According to DuPont, Aproach (Picoxystrobin) is effective against $S$. sclerotiorum, frogeye leaf spot (Cercospora sojina), brown spot ( $S$. glycines) and Asian soybean rust (Puccinia pachyrhizi) in soybeans. Out of these, in vitro results showed Aproach was effective against and $S$. glycines as labeled but also effective against $C$. truncatum and $F$. virguliforme (not labeled). Although, Aproach was not the highest radial growth reducer of $C$. truncatum compared with Headline EC, Priaxor, Quadris, and Stratego YLD but was significantly higher than Sercadis (Figures 2A and 2B). Similarly, Aproach has effectively reduced the radial growth of $F$. virguliforme on par with Priaxor, and significantly lower than Stratego YLD but higher than other fungicides (Figures 2A and 2B). Whereas, in $S$. glycines, Aproach showed lowest inhibition diameter compared with Priaxor, Stratego YLD and Headline EC. Also, Aproach was ineffective on P. irregulare, M. phaseolina, $R$. solani (not listed on the label) and $S$. sclerotiorum (listed on the label). Similar in vitro observation has been reported about Aproach on $S$. sclerotiorum compared with Endura fungicide [33]. As per the label, Aproach should have suppressed growth of $S$. sclerotiorum instead it was on par with control plates both in terms of mycelial growth and also reproduction of sclerotia (Figure $2 \mathrm{~B}$ ). Chances are the product may be effective against ascospores than suppressing sclerotia production per se or the product may show better results in field conditions (either seed treatment or foliar applied) compared with in vitro tests. We do not intend to extrapolate ineffectiveness of Aproach against $S$. sclerotiorum based on the in vitro results as was suggested by De Clercq [34].

According to Arysta Lifescience, Evito (fluoxastrobin) with its advanced Strobilurin chemistry, delivers outstanding control of alternaria leaf spot (Alternaria spp.), anthracnose (Colletotrichum spp.), brown spot ( $S$. glycines), cercospora blight (Cercospora kikuchii), frogeye leaf spot (C. sojina), pod and stem blight (Diaporthe phaseolorum), rhizoctonia aerial blight $(R$. solani) and rust $(P$. pachyrhizi) in soybean. Out of these, in vitro tests of Evito were against labeled $C$. truncatum, $R$. solani, and not labeled $F$. virguliforme, $M$. phaseolina, $P$. irregulare, and $S$. sclerotiorum. Evito was as effective as Aproach on $C$. truncatum, but it did not show any effect on other pathogens tested including $R$. solani (Figures 2A and 2B). Also, field tests by Giesler [35] showed, no significant effect on brown spot ( $S$. glycines) severity (11-47 days after spray) and yield.

Three BASF Corporation products Headline, Priaxor, and Sercadis were tested. According to BASF, Headline (pyraclostrobin) applied infurrow on corn and soybean, helps control soil borne R. solani while providing plant health benefits, including healthier, more vigorous roots. In addition, it helps improve seedling health and allows for more rapid and uniform emergence even under cold and wet conditions. Plus the EC formulation can be tank-mixed with a liquid fertilizer for easy application. In in vitro tests, Headline has significantly $(\mathrm{P}<0.05)$ reduced the radial growths of $C$. truncatum, $F$ virguliforme, $M$. phaseolina, S. sclerotiorum (not labeled) and R. solani (labeled) but not $P$. irregulare (Figures $2 \mathrm{~A}$ and $2 \mathrm{~B}$ ). In vitro results showed $C$. truncatum, $F$. virguliforme, $R$. solani, $S$. sclerotiorum and $S$. glycines significant sensitivity to Headline. Interestingly, Headline, either solo or in combination with other fungicides and insecticides significantly $(\mathrm{P}<0.05)$ suppressed brown spot $(S$. glycines $)$, and frogeye leaf spot $(C$. sojina) across 11 seasons, with an average yield advantage of $5 \mathrm{bu} / \mathrm{ac}$ or $0.26 \mathrm{mt} / \mathrm{ha}$ (range 2 to $8 \mathrm{bu} / \mathrm{ac}$ or 0.10 to $0.41 \mathrm{mt} / \mathrm{ha}$ ), even under low diseases pressure [36]. Although, no significant advantage of Headline (solo or combination) in plots with sudden death syndrome $(F$. virguliforme) and white mold ( $S$. sclerotiorum), but significant $(\mathrm{P}<0.05)$ yield increase was observed over unsprayed controls indicating plant health benefits of spray [36].

Priaxor" (fluxapyroxad + pyraclostrobin), as a foliar spray is effective against alternaria leaf spot (Alternaria spp.), anthracnose ( $C$. truncatum), Asian soybean rust* $\left(P\right.$. pachyrhizi ${ }^{\star}$ not registered for use in California), brown spot ( $S$. glycines), Cercospora blight $(C$. kikuchii), frogeye leaf spot (C. sojina), pod and stem blight ( $D$. phaseolorum), Rhizoctonia aerial blight ( $R$. solani), suppression only white mold (S. Sclerotiorum) and southern blight (Sclerotium rolfsii) as per the label. Out of this list, in vitro test was conducted against labeled $C$. truncatum, $R$. solani, S. glycines, and S. sclerotiorum, and not labeled $F$ virguliforme, $M$. phaseolina, and $P$. irregulare. Priaxor was significantly effective in reducing the radial growths of labeled and not labeled pathogens (except $P$. irregulare) compared with control (Figures $2 \mathrm{~A}$ and $2 \mathrm{~B}$ ). Priaxor was also significantly effective in field sprays against white mold and yields $[37,38]$ and significant effect on white mold but not on yields [39].

A third BASF product, Sercadis (fluxapyroxad) fungicide provides both preventive and post infection sheath blight of rice ( $R$. solani) control with long-lasting residual. Irrespective of crop, Sercadis significantly reduced radial growth of $C$. truncatum (not labelled) and R. solani (labelled) compared with control (Figures 2A and 2B). We do not wish to speculate if Sercadis could be effective against these two soybean pathogens in field tests. 
According to Bayer CropScience, Stratego ${ }^{\circ}$ YLD (prothioconazole + trifloxystrobin) controls alternaria leaf spot (Alternaria spp.), anthracnose (C. truncatum), Asian soybean rust (P. pachyrhizi), brown spot (S. glycines), cercospora blight (C. kikuchii), frogeye leaf spot $(C$. sojina), pod and stem blight (D. phaseolorum), powdery mildew (Microsphaera diffusa), Rhizoctonia aerial blight ( $R$. solani). Out of this list, in vitro efficacy tests were conducted against $C$. truncatum, $R$. solani, S. glycines (listed on label), F. virguliforme, M. phaseolina, and S. sclerotiorum (not listed on label). In vitro results showed significant reduction in growth of both labeled and not labeled pathogens except $P$. irregulare compared with control (Figures $2 \mathrm{~A}$ and $2 \mathrm{~B}$ ). Foliar spray of Stratego YLD, did not show significant effect on white mold and yields [37], and on sudden death syndrome and white mold and yield [8]. Also, field tests by Giesler [35] indicated, no significant effect on brown spot severity (11-47 days after spray) and yield. In 2015 seed treatment tests with these products, some of the fungicides showed significant increase in stand count, suppression of $F$. virguliforme and R. solani compared with control [40].

\section{Acknowledgements}

Sincere thanks to Mark A. Storr and Gary Schmitz of BASF chemical company for providing product samples and partial funding support of this research.

\section{Disclaimer}

Products tested in this study do not imply endorsement of one company over another, nor was discrimination intended against any similar products. BASF had no role in the data collection and analysis or the preparation of this article.

\section{References}

1. Hymowitz T, Nelson RL, Sinclair JB, Hartman GL (2015) History and growth of the soybean plants. The American Phytopathology USA.

2. USDA (2015) World Agricultural Production. United States Department of Agriculture/Foreign Agricultural Service.

3. Hartman GL (2015) Worldwide importance of soybean pathogens and pests. The American Phytopathology USA.

4. Hartman GL, Rupe JC, Sikora EJ, Domier LL, Davis JA, et al. (2015) Soybean diseases in Argentina, Brazil, Canada, China, India and Japan. The American Phytopathology USA.

5. Wrather JA, Koenning SR (2006) Estimates of disease effects on soybean yields in the United States 2003 to 2005. Journal of nematology 38: 173.

6. Bassanezi R, Amorim L, Hau B, Berger R (2001) Accounting for photosynthetic efficiency of bean leaves with rust, angular leaf spot and anthracnose to assess crop damage. Plant Pathology 50: 443-452.

7. Shtienberg D (1992) Effects of foliar diseases on gas exchange processes: a comparative study. Phytopathology 82: 760-765.

8. Wrather J, Koenning S (2009) Effects of diseases on soybean yields in the United States 1996 to 2007. Plant Health Progress.

9. USDA-NASS (2013) NASS releases 2012 Chemical use data for soybeans and wheat.

10. Bradley C (2008) Effect of fungicide seed treatments on stand establishment, seedling disease, and yield of soybean in North Dakota. Plant Disease 92: 120-125.

11. Mueller D, Hartman G, Pedersen W (1999) Development of sclerotia and apothecia of Sclerotinia sclerotiorum from infected soybean seed and its control by fungicide seed treatment. Plant Disease 83: 1113-1115.

12. Bartlett DW, Clough JM, Godwin JR, Hall AA, Hamer M, et al. (2002) The strobilurin fungicides. Pest management science 58: 649-662.
13. Broders K, Lipps P, Paul P, Dorrance A (2007) Evaluation of Fusarium graminearum associated with corn and soybean seed and seedling disease in Ohio. Plant Disease 91: 1155-1160.

14. Ramirez ML, Chulze S, Magan N (2004) Impact of environmental factors and fungicides on growth and deoxinivalenol production by Fusarium graminearum isolates from Argentinian wheat. Crop Protection 23: $117-125$.

15. Ellis M, Broders K, Paul P, Dorrance A (2011) Infection of soybean seed by Fusarium graminearum and effect of seed treatments on disease under controlled conditions. Plant Disease 95: 401-407.

16. Chala A, Weinert J, Wolf $G$ (2003) An integrated approach to the evaluation of the efficacy of fungicides against Fusarium culmorum, the cause of head blight of wheat. Journal of Phytopathology 151: 673-678.

17. Yoshida M, Nakajima T, Arai M, Suzuki F, Tomimura K (2008) Effect of the timing of fungicide application on Fusarium head blight and mycotoxin accumulation in closed-flowering barley. Plant Disease 92: 1164-1170.

18. Paul P, Lipps P, Hershman D, McMullen M, Draper M, et al. (2008) Efficacy of triazole-based fungicides for Fusarium head blight and deoxynivalenol control in wheat: A multivariate meta-analysis. Phytopathology 98: 999-1011.

19. Hewitt HG (1998) Fungicides in crop protection. CAB International.

20. Powelson ML, Inglis DA (1999) Foliar fungicides as protective seed piece treatments for management of late blight of potatoes. Plant Disease 83: 265-268.

21. Conner A (1983) The comparative toxicity of vineyard pesticides to wine yeasts. American Journal of Enology and Viticulture 34: 278-279.

22. Adams PB, Wong JAL (1991) The effect of chemical pesticides on the infection of sclerotia of Sclerotinia minor by the biocontrol agent Sporidesmium sclerotivorum. Phytopathology 81: 1340-1343.

23. Magaldi S, Rios A, Hartung C, Verde G, Spencer L, et al. (2001) In vitro susceptibility to fluconazole of Candida spp. isolates comparing three different methods. Journal de mycologie médicale 11: 123-126.

24. Anahosur K, Padaganur G, Hegde R (1977) Laboratory evaluation of fungicides against Cylindrocladium quinquiseptatum, the causal organism of seeding blight of Eucalyptus hybrid. Pesticides 11: 44-45.

25. Corden ME, Young R (1962) Evaluation of eradicant soil fungicides in laboratory. Phytopathology 52: 503-509.

26. Everett K, Owen S, Cutting J (2005) Testing efficacy of fungicides against postharvest pathogens of avocado (Persea americana cv. Hass). New Zealand Plant Protection 58: 89-95.

27. Rahman M, Begum M, Alam M (2009) Screening of Trichoderma isolates as a biological control agent against Ceratocystis paradoxa causing pineapple disease of sugarcane. Mycobiology 37: 277-285.

28. Al-Rahmah AN, Mostafa AA, Abdel-Megeed A, Yakout SM, Hussein SA (2013) Fungicidal activities of certain methanolic plant extracts against tomato phytopathogenic fungi. African Journal of Microbiology Research 7: 517-524.

29. Mostafa AA, Al-Rahmah AN, Adel-Megeed A (2011) Evaluation of some plant extracts for their antifungal and antiaflatoxigenic activities. J Med Plant Res 517: 4231-4238.

30. Shrestha SK, Fosso MY, Garneau-Tsodikova S (2015) A combination approach to treating fungal infections. Scientific reports 5.

31. Neely D (1969) The value of in vitro fungicide tests. Biological notes no 064 .

32. Abramoff MD, Magalhaes PJ, Ram SJ (2004) Image Processing with ImageJ. Biophotonics International 11: 36-42.

33. Anonymous (2013) Growing season BASF fungicide solutions.

34. De Clercq E (2005) Recent highlights in the development of new antiviral drugs. Current opinion in microbiology 8: 552-560.

35. Giesler L (2012) UNL studies effect of foliar fungicides and insecticides on soybean disease severity and yield.

36. Navi SS, Yang XB, Li X, Jing L (2015) Effect of pyraclostrobin spray either solo or in combination with other chemicals on soybean diseases and yield response in Iowa from 2003 to 2013 USA. 
Citation: Navi SS, Rajasab AH, Yang XB (2016) In Vitro Evaluation of Commercial Fungicides against Some of the Major Soil Borne Pathogens of Soybean. J Plant Pathol Microbiol 7: 340. doi:10.4172/2157-7471.1000340

Page 8 of 8

37. Navi SS (2014) Efficacy tests of foliar fungicides on soybean diseases and yield during 2012 and 2013 growing seasons in Northeast Iowa.

38. Navi SS (2014) Evaluation of application rates of fungicides on soybean diseases and yields.
39. Navi SS (2013) Effect of foliar fungicides at R3 growth stage on soybean disease and yield.

40. Navi SS (2015) Evaluation of foliar fungicides as protective seed treatments for management of soybean diseases. 